\title{
Chapter 5 Julia's Prosody
}

The antiquated Radio Shack cassette player, rummaged from the bottom of a storage box of long discarded electronics, emits the high-pitched timbre of Julia's voice from 1989, as I, now a middle-aged woman, am transported back to when a wideeyed history student listened with rapt attention to tales of heroic women casting aside caution and convention, to tear at the fabric of a regime woven from lies. Julia's voice reverberates in her story-her prosody:

I was just a kid, only 17. I still cannot believe I was able to pull through it all, the way I did. The police did not know my name, but Berta ${ }^{1}$ betrayed me after a serious beating while she was being interrogated. I don't blame her. No. She ended up being the Party's scapegoat when many others opened their mouths too. Berta and I spent our time together in jail. No. I do not hold it against her.

Berta was from Tolosa, Guipúzcoa, a 20-year-old student of Biological Sciences and militant of the PCE cataloged by the police as someone who "had created volatile subversive situations violating article 28." She had been first arrested on October 16, 1970, for distributing illegal propaganda pamphlets together with Jesús Carreño Tenorio in the Camino de Ronda area of Granada. The leaflets supported the construction general strike in July that same year and protested the police assassination of three workers. Berta was the first detainee during the 1970-71 State of Emergency, on December 15, 1970. Spending the mandatory 72 hours in a cell in the Plaza de los Lobos police station, she was interrogated and severely beaten and then transferred to the Provincial Prison of Granada. Passed to the TOP, and convicted for the crime of sedition and provocation, she was sentenced to three months imprisonment. She remained in prison by order of the Civil Governor who did not let her out even after posting the required bail of 10,000 pesetas. Her behavior was classified as "bad." The proceedings for her freedom were unsuccessful until the month of May. She was accused by the Public Prosecutor of terrorism, illicit association, and illegal propaganda. Martínez Foronda and Sánchez Rodrigo, Mujeres en Granada por las libertades democráticas, 48. On the bail payment irregularities, see Informe del Departamento de Información del Distrito de Granada, "Situación de los presos políticos en Cranada," 14 de abril de 1971, in Archivo Universidad de Granada, Secretaría General del Rectorado, Asociaciones de Estudiantes, 69/71, leg. 23-272. 
The State of Emergency ruined our Christmas of 1970 for sure. There were no "noches buenas"2 but rather many rotten nights from December 14 on. Carols and fear do not syncopate. I should have known, having been raised by a father who is a musician. Though, when you think about it, my dad being in the army may have furnished some intuition on how to harmonize terror and tone. I must say, he was a sweet man to my sister and me, always. He had a sweet spirit like the sound of the oboe he played so artfully. I know how much pain I caused my family. I was very sheltered, and they had no idea how deeply involved I was. They only saw their 17-year-old daughter still living at home, excelling in her studies as a student of Geography and History at the University of Granada.

The morning after Christmas, I woke up with a premonition. I knew of the arrests of my comrades and worried that my parents would find the large stacks of pamphlets I was hiding at home. I figured I should contact another comrade to dispose of the propaganda, so after breakfast I told my father I had to run an errand. For some strange reason, he insisted on coming with me. The police were already waiting for me as we stepped out onto the street.

No doubt my arrest shocked my family. We were so ordinary, you know. I never felt the need to rebel against a tyrannical father like other friends did. No, that was not what led me to the Communist Party. I was very naïve, confused, eager to make my mark on the world. My adolescent curiosity had led me to read Josés ${ }^{3}$ work and even turn into a pious daily communion churchgoer for an entire summer. At home, religion was always pro-forma, never felt. I am proud to say my parents never sent me to a nunnery school. My parents did not think deeply about anything. Both were compliant with religious rituals, never politically engaged. My father had to fight on the "Nationalist" side, though never was a committed fascist. He was someone without strong beliefs, unwilling to think things through.

2 Julia Cabrera, interview by author, tape recording in Granada, June 1989.

3 José Antonio Primo de Rivera (1903-1936), son of former dictator Ceneral Miguel Primo de Rivera (1870-1930) and founder of Falange Española in 1933. He had been a deputy to the Republican parliament. In 1936 he was executed in Alicante by the Republican Government as the Spanish Civil War erupted. José Antonio became mythologized by the regime. His sister Pilar Primo de Rivera (1907-1991) was the head of the Falangist Female Section (Sección Femenina de Falange) founded by a select elite of university women in 1934. The Female Section became the only official women's organization in charge of indoctrinating Spanish women in national duties for the regime until it was dissolved in 1977. The bibliography on these topics is extensive. A few key readings include: Stanley Payne, Falange: A History of Spanish Fascism (Redwood City, CA: Stanford University Press, 1961); A History of Fascism, 1914-1945 (Madison: University of Wisconsin, 1995); and Fascism in Spain 1923-1977 (Madison: University of Wisconsin, 1999). The bibliography on Sección Femenina's history is exhaustive. Some recent publications include: Inbal Ofer, Señoritas in Blue: The Making of a Female Political Elite in Franco's Spain (Brighton: Sussex Academic Press, 2009); Sofía Rodríguez López, El patio de la carcel: La Sección Femenina de FET-JONS en Almería (1937-1977) (Sevilla: Centro de Estudios Andaluces, 2010). 
Dad had briefly been a carpenter in Baeza, his hometown. ${ }^{4}$ Since a few men in his family played in the village band, they encouraged his interest in music. My mother was from the same town. They belonged to the lower middle class but had aspirations to climb up the social ladder. Just married, my father was stationed in Segovia, where my sister and I were born. We lived there until I was nine or ten years old, when we moved to Granada because my father wanted to bring his family closer to his hometown.

I truly feel like I'm from "Graná!" They may have delivered me in Segovia, but I identify as Andalusian in spite of the Castilian remnants in my speech. I am southern most definitely. I suffered the teasing from other children when we moved here. First, I attended a public, or as they called it then, "national" school in Plaza Nueva as we settled in the historic district of Paseo de los Tristes at the foot of the Alhambra. I missed my teacher, Doña Visi, from Segovia. It was she who opened my mind to learning. She was brilliant, one of the many teachers from the Republic ostracized by the regime after the war, making it impossible for her to find a job in the school system. A group of children attended her home school instead, and we received the gift of knowledge. Then in Granada I was punished severely in my new school by a mean, sanctimonious teacher who ridiculed me in front of my classmates when she discovered I had taken communion without keeping the mandatory fast. The daily anxiety I faced at school made me sick. I developed an ugly rash on my face from some of the stress that comes back every time I get anxious. My torture ended when our family moved to the newly minted working-class neighborhood of Los Pajaritos near the train station. There I finished my prep to enter the baccalaureate at a private school where I was able to assist the teacher with the geography lessons. Doña Visi's teachings still carried me through after all those years.

I attended Instituto Ganivet, the girls-only high school located next to the boys' school, Padre Suarez in Gran Via. While in high school I started to engage with other students in certain minimal activism in solidarity with the college students who were on strike the year I was finishing my entrance exams for the university. I remember we organized a twentyminute protest, refused to enter the mathematics class until twenty minutes into the lecture, all to show our solidarity with the college students whose cause we would join within a year. I, only 17 years old, was eager to fight for a cause by the time I enrolled in October 1969, my freshman year.

I knew nothing about politics, and yet within a couple of months I had joined the Communist Party. It was by happenstance rather than by design. That was the firstyear the university opened a new building for the Philosophy and Letters students, the monumental sixteenth-

4 The ancient town of Baeza is located about $48 \mathrm{~km}$ northeast of the provincial capital of Jaen in Andalucia. It borders on the east with the municipality of Úbeda, with which it shares the capital of the historic Comarca de La Loma. In 1960 the total population was 15,461, decreasing slightly to 14,834 in 1970. The rich history and monumental Renaissance architecture led UNESCO to declare it a World Heritage site in 2003 . Today it hosts one of the headquarters of the International University of Andalusia.

5 Traditional way local granadinos refer to their city. Accentuating the middle syllable and dropping the last one in the manner of the Andalucian dialect: Graná(da). 
century Hospital Real by the Triunfo Gardens. Magnificent! There were so many people and obviously most of us were women, as you know. The SDEUG had been established a year earlier in 1968, ${ }^{6}$ and there were delegate elections in different classes. I could not believe only guys were nominated in a class where women were the majority, so I instinctively volunteered to be a delegate. Obviously, the candidates were all members of political organizations, mainly the PCE. ${ }^{7}$ And in January 1969 there had been a State of Emergency that led to several arrests among them. ${ }^{8}$ But I just jumped to the front, a total unknown. I suddenly was terrified, con-

In October 1967, delegates from the universities of Barcelona, Madrid, Oviedo, Santiago, Seville, Valencia, Valladolid, Zaragoza, Bilbao, and Málaga met in Madrid, and in the academic year 1967-1968 democratic student unions were created in most of the universities. Two factors were definitive for their short existence, although in different ways: the repression and the radicalization of a part of the student militancy.

As Carme Molinero and Pere Ysàs point out: "At the universities in the mid-sixties students' representatives in the SEU were chosen by the students themselves. This situation allowed them to call assemblies to deal with certain academic or cultural issues, where it could be disguised as formally 'of the SEU.' For other matters (meaning political matters), the assemblies were held outside the official channels. By 1965 these other assemblies were already more and more frequent than the meetings of the Falangist SEU, particularly in the case of Barcelona. The agenda included: first, students' self-organization outside the SEU; second, solidarity with social sectors the dictatorship repressed; and third, the configuration of alternative university and culture to Franco's university and culture. This third aspect included the organization of cultural (or political-cultural) activities that clashed with the strict censorship imposed by the regime. The communist militants played a fundamental role between 1965 and 1966 culminating in the process of student rejection of the Franco regime that began in 1956. The PCE called its university militants to try to advance in the process of self-organization that it presented as parallel to the push of Workers' Commissions. Aware of the different conditions of the various university districts, the call was to promote the elections, although adapting to local circumstances. In some university districts free elections could be called, which would serve to consolidate the structures of the Student Democratic Union (SDEUG, Sindicato Democrático de Estudiantes, UC stands for University of Granada); in most cases, it would only be possible to present candidates in the official elections to win spaces of action." Pere Ysàs Solanes and Carme Molinero, De la hegemonía a la autodestrucción: El Partido Comunista de España (1956-1982) (Barcelona: Editorial Crítica, 2017), loc. 879 of 10995, Kindle.

8 According to Carme Molinero and Pere Ysàs, " $[t]$ he repressive threat was effective, and many opponents fled their homes. The classified information kept in the Ministry of Information and Tourism indicates that on March 18, 1969, after successive police operations, 735 people were detained or under house arrest, of which 315 were students and 420 had other professions. Of the 735 , there appeared as 'domiciled' 159 , while of the rest, 196 were at the disposal of the military authority, 212 of the civil jurisdiction, and 168 of the governmental authority. The most affected organization was the Communist party and, particularly, the PSUC (The Partit Socialista Unificat de Catalunya or Socialist Unified Party of Catalonia). More than seventy militants were arrested, and fifty others had to leave work and home. [...] The militant overexertion had to be very important. To gauge what the term 'overexertion' could mean, it must be borne in mind that a large part of the communist force depended on the character and fortitude of the base: men and women with a deep sense of personal sacrifice materialized 
scious of my move, having to prepare a little speech for my classmates. I was saying to myself, "What do I say now?" I came up with some sort of spiel on the value of cultural matters or something like that. Surprisingly, I was elected by my fellow women in the classroom. Then and there the PCE came to recruit me, and before the end of the academic year I had joined them.

I did not know a thing about Marxism. Everything I learned about it, I learned inside the Party. I remember that time with great affection. We owe the Communist militants all the gratitude in the world because they devoted their lives to change the course of our nation. They convinced me of the worthy cause in which I was embarking. Along with the Christians in FECUN, the PCE carried the resistance ${ }^{9}$ in the university and led the collaboration with the labor movement. I realize now how hard the collaboration with FECUN was, but at the same time we all found ways to overcome those differences.

The most stimulating aspect of my militancy was the high-level theoretical discourse that sustained our political action. I admired Socorro and Jesús, as well as Joaquin, who taught me so much in the Party seminars. In those seminars we discussed policy and strategies as well as texts by Marx, Lenin, etc. All these activities were prohibited, of course, and kept secret through a network of contacts that linked the various cells. ${ }^{10}$ It was in hindsight comical but

in the form of renunciation in their professional career, in private life, and personal freedom in the form of years of imprisonment. Their militancy completely conditioned their life, becoming the axis of their existence. Until the 1970s, underground activism forced militants to a double life, as only those closest to them (and not always those) knew of their militancy. Fear was their most intimate companion and, almost from the moment of entering the party, that individual had to prepare psychologically for detention. In addition, repression had more consequences than the detention and torture of the militants on the one hand, and the need to rebuild the collective organization on the other. It affected the self-esteem of the militants. When there was a 'fall, ' the control system of the situation on the part of management was based on analyzing who had been the first detainee and what had been disclosed; from here the 'responsibilities' were refined. This meant placing all 'responsibility' on the detainees themselves." Ysàs Solanes and Molinero, De la hegemonía a la autodestrucción, loc. 1307 of 10995, 1321 of 10995, 1335 of 10995, Kindle.

9 Carme Molinero and Pere Ysàs Solanes point out that in the mid-sixties, the communist militants were the axis of the student movement focused on the goal of self-organization. Students formulated clear objectives of alternative learning spaces to the Francoist university while developing a method of action that was supported by concrete demands and by the full involvement of students in the organization, but that design, while appropriate and adapted in the working world, was not able to take hold and expand in the university context. Fundamentally, the university was a very specific framework that was easily isolated from the general context, where the student movement had managed to put an end to the APE before they were born. Ysàs Solanes and Molinero, De la hegemonía a la autodestrucción, loc. 1014 of 10995 , Kindle.

10 In his memoirs Autobiografía de Federico Sánchez, Jorge Semprún characterized as problematic and ineffective the PCE system of contacts in the clandestine operations inside Spain. Federico Sánchez was one of Semprún's clandestine aliases during his communist militancy. This 
necessary for our safety. We Communists were a relatively small group, but at the same time, we had a large impact on the University, mainly due to the reluctance of other groups to step up and oppose the regime. Our organization was very hierarchical, authoritarian really. I myself was rather undemocratic, even harsh, when I was in charge of a cell, but at the time it had to be that way.

I did not have a record, but Berta turned me in. I don't blame her. There were others who were rats, and nothing came of their disloyalties. Many things went wrong. We got careless. Many times, we would continue our secret meetings over a beer in a bar, even though we weren't

work is Semprún's bitter criticism of the PCE after his expulsion, along with Fernando Claudín, in 1964 upon disagreements with Santiago Carrillo and the older generation of Communists (those who fought during the Spanish Civil War), who he characterized as having authoritarian and personalist (read Stalinist) tendencies. In March 1960, Semprún published an essay in the Party's journal Nuestra Bandera about his concerns regarding the clandestine methods and the so-called "contacts system": "In recent years, the most widespread method of organization and direction has been the one that you will allow me to define now as a contact system. Around a small group of leading comrades, many of whom, if not all of them, were obliged to carry out their work in conditions of the most rigorous secrecy, a whole network of individual contacts was established, with comrades of such and such a company, of this or that neighborhood, of that town, of that village. This network of contacts forced the communist leaders to maintain a real chain of appointments and interviews. [...] The drawbacks and negative features of this contact system do not seem to be difficult to point out. It is evocative that in a contact, deep political problems cannot seriously be discussed. Things are limited to a mere exchange of information and opinions, to a simple transmission of general orientations, and precisely because of this, abstract information most of the time. In the second place, the system of contacts constitutes, independently of the will of the comrades, a brake on the development of the organization and on the elevation of the political level. And this is due to several reasons. Because it hinders the incorporation to the Party of the revolutionary worker youth, of the young unorganized communists that today are counted by dozens in our country. Because the contacts are established logically, with the comrades already known, who are usually those with a police record, who have been in jail, which objectively and subjectively restricts their mobility, their capacity to accelerate the massive entry into the party of the new revolutionary forces. Because the contact system also divides the real possibilities of action of the base organizations, it is not rare the cases in which we have had in a certain company, or in a certain place, a half dozen contacts, even more, which means that we do not have a real organization. And above all, because the contact system makes the political life of the party groups precarious, both in the aspect of political discussion and the elaboration of concrete issues and in the continuity of the work. The system of contacts does not stimulate the initiative of the comrades of the grassroots organizations, of the leading business or local cadres; it hinders the essential vivifying current, that must occur from the bottom up in the Party; it makes this current almost always one-sided: to a contact one usually goes with the spirit of informing and knowing that 'the comrade' is bringing from 'above;' now, this comrade from 'above,' however capable, can only bring general orientations, possibly abstract, because he does not know the concrete issues, because he does not dominate them." Jorge Semprún, Autobiografía de Federico Sánchez (Barcelona: Editorial Planeta, 1977), 190-92. 
supposed to fraternize in public. Ours was not a very well-kept secret! And so, I think there was a certain level of negligence or complacency on our part...mistakes we paid for dearly.

For me, personally, the worst experience that fall happened in the police precinct. I pretended I knew nothing for as long as I could endure. You know how they approach women, right? We are whores to start off with. Then they are screaming in your ear how worthless you are. I was only seventeen, my life had just begun. It was in the precinct that my biological condition as a woman became a source of humiliation at the hands of the police. Because of the panic, I got my period. Bleeding down my legs in the cell of the precinct added another layer of vulnerability and a blow to my dignity, as I had to ask the guards for a pad. The latrines were revoltingly filthy. Of course, our male comrades did not know the half of it. An annoyance, a pest, a girl in jail. Precisely in those moments, your body turns into another enemy. But then, in spite of it all, I took advantage of the fact that they did not know me, so I played dumb. A girl in jail, a pest, an annoyance. Playing dumb turned into my weapon of choice. I saw others carried out of the interrogation and into the cell, bleeding from the beatings as I bled too, from my period, as if my body, my entrails, had already been crushed by an invisible torturer. ${ }^{11}$

The brutal police treatment in the precinct of Los Lobos did not discriminate between men and women. The repression against women students intensified between 1972 and 1977 . One of the most dramatic incidents took place in the precinct in 1975 and involved Carmen, two years younger than Julia and a member of the Communist Party, like the latter. Carmen became head of the Philosophy and Letter's College party's cell and soon after became part of the executive provincial committee. Her marked activism placed her on the police most wanted list. And so, in a campaign to encourage participation in the student elections and after placing a poster in the Royal Hospital with another comrade, Encarnación, they were arrested on Santa Bárbara street at 9 o'clock in the morning on November 13, 1975 (only a week later Franco was dead). "We were walking down towards Sciences' College keeping on the left of the sidewalk away from the street traffic when suddenly some individuals got out of a car and identified themselves as policemen and told us we were arrested. From there, without further explanation, they took us to Duquesa Street, two of them behind and two others in front of us." Once they arrived at the precinct in Plaza de los Lobos, they were booked and taken to their respective homes, where, before their parents and a couple of neighbors as witnesses, the police searched their homes but did not find or take anything. After the search they returned to the police station to give their statement. During their interrogation, a policeman put a gun to Carmen's temple and threatened to go after her father. Under the newly approved Antiterrorist law, Carmen feared the possibility of ten days of solitary confinement and new violent interrogations. Such grim prospects led her to hurt herself by violently hitting her head several times against the stone bench in her solitary cell. She immediately started convulsing and lost consciousness. First, they took her in a police car rather than an ambulance to the Hospital of San Juan de Dios, where the doctor on duty refused to treat her. In the same car, they then drove her to the Psychiatric Hospital where she was admitted and treated. The following day, Judge Terrón met with a court clerk and a forensic doctor to take a statement and informed her that she was accused of illicit association and distribution of illegal propaganda. Meanwhile, the students placed a poster denouncing her situation which was promptly removed by the authorities, as it stated that "on Saturday, the 15th, she was admitted to the Psychiatric Hospital, victim of a nervous breakdown, the student of Stories, 
As a member of the Communist party I was charged with illegal association and distribution of subversive propaganda. I accepted it, recognized my sins, confessed, "yes I was illegal!" to end it all. ENOUGH! On my transfer from the precinct to the trial court something unexpected, almost poignant happened. It snowed. That drew me back in time to a cherished childhood memory.

Del cielo gris, en silencio, /From the gray sky, in silence,

los copos de nieve bajan:/ snowflakes come down:

son petalos de azucena, / Like lily petals,

plumas de palomas blancas. / or feathers of white doves ${ }^{12}$

I remembered my winters in Segovia when the snow used to freeze the ground, and we did not go to school. The joy as we woke up in the morning and ran to get in bed with our parents. One of those divine memories from my childhood. I loved the snow, even more in Granada where it was so rare. But somehow something wonderful happened in the midst of this particular 1970 ugly Christmas season. I said to myself with an ironic smile, "Is this for real? Now that it starts snowing, they decide to lock me up!" The first snowfall since we moved to Granada, nine winters waiting for it and when it came, I was inside the police van.

Jarring as was my entry into prison, it turned into a forced gynaecium for the next four months. The very few women-five, maybe six, political prisoners-already were sitting around what every sitting room in every Spanish home has in winter: a warm round table we call "mesa Camilla" with its brazier underneath the table and its flowing skirt covering the legs of the women. That was New Year's Eve. On this occasion, the five or six prisoners, along with the women guards, were enjoying some shrimp.

We had certain advantages over the common inmates, mostly whores and petty thieves. I remember one of the guards with special affection. She treated us with maternal interest. Berta, who had turned me in, was among the women. After a couple of days, Arantxa arrived as well, and the guards arranged a common space for us upstairs called the "brigade," where they gave us some bookshelves for our books and a small desk for studying...it was our own private space, our apartment of sorts! Only we were under lock and key and could not leave. We were able to write letters to our male comrades imprisoned on the other side of the facility. I remember the love letters between Arantxa and one of the guys. Our families brought us food, and we cooked and shared it with every inmate. Yes, definitely an experience I remember as not too traumatic, yet one that stays with you for the rest of your life. The psychological scars show

Carmen M., had enough bruises on her body to demonstrate the mistreatment received during 48 hours that she had remained in police custody." On November 26, 1975, she finally left the Psychiatric Hospital, released from police custody and receiving a general pardon after Franco's death. Entry record in CC 064098 of November 14, 1975, in AHCCG, File 1325 A, quoted in Martínez Foronda and Sánchez, Mujeres en Granada, 159-61.

12 Angela Figuera Aymerich, "Invierno," in Obras Completas (Madrid: Ediciones Hiperión, 1986), 432 [my translation]. 
up from time to time as a bad temper unexpectedly surfacing in the idleness of daily nothings. Things I never experienced before being imprisoned suddenly became regular occurrences. I never suffered from painful menstruation cycles before my arrest, but in jail every month I agonized in pain and started taking Buscapina. ${ }^{13}$ You think everything is fine but no, there is something within yourself and in my case, it was through my period that it manifested itself over and over again.

My family suffered as well. They put up with it, my mother much better than my father. As an army officer, he had an especially hard time even though there were so many army families whose children had joined the anti-Francoist resistance. My parents considered the whole affair a youthful indiscretion. They believed I had been deceived into joining the wrong cause. As a result, when I was released and sent home, they tried to confine me to the house.

This led to a terrible fight. At one point I took a small suitcase and left. I told them, "Look, I've been locked up for months... You're locking me up again? NO! This I will not stand.... You must change your attitude." They had to accept it. "I must be free, be able to go out, interact with people." I assured them no one had fooled me or forced me to think or act against my will, that my convictions guided my actions and not only that, I intended to remain a Communist and keep fighting.

In reality, it was not possible to go back to the way it was. For security reasons, the party ostracized those of us who were imprisoned. They knew the police were watching us. This helped me to assure my parents that I would not get into any more trouble. I made my parents see the absurdity of their qualms, made them see how I must be loyal to those very people I had been in jail with, while at the same time not be able to acknowledge my old comrades on the street. This was not only bizarre but also painful because they were more than friends to me. So, I confronted my parents that day in despair as I readied myself to leave the house. Our own home turned into a mini civil war, one that was being fought all over Spain between parents, who had long ago accepted their fate, and their children who did not. No, I did not surrender nor was I about to allow my parents to lock me up again. My five months imprisonment had been long enough. ${ }^{14}$

13 For more than fifty years Buscopan ${ }^{\circledast}$ has been used to treat abdominal spasms. It relaxes the contracted muscles of the digestive tract and relieves pain caused by spasms.

14 Julia's experience highlights the significance of space as an active entity in the repressive mechanisms of control and discipline, which extended beyond the prison walls to the everyday life under Franco. These repressive technologies are certainly mediated by the gender distinctions deployed by the regime as well. For more on the experience of women in the Francoist prisons see: Ricard Vinyes, Irredentas (Madrid: Temas de Hoy, 2009); M. Edurne Portela, "Writing (in) Prison: The Discourse of Confinement in Lidia Falcón's En el infierno" Arizona Journal of Hispanic Cultural Studies 11 (2007): 121-36; Carme Molinero and Margarida Sala, Una inmensa prisión: Los campos de concentración y las prisiones durante la Cuerra Civil y el Franquismo (Barcelona: Crítica, 2003); Rodolfo Serrano, Toda España era una carcel: Memoria de los presos del Franquismo (Madrid: Aguilar, 2002); Tomasa Cuevas and Mary E. Cilles, Prison of Women: Testimonies of War and Resistance in Spain, 1939-1975 (Albany: State University of New York Press, 1998); Janet Pérez and Cenaro J. Pérez, "Prison Literature: Introduction," Monographic Review/ 
I won't lie to you. Those years of my youth were so precious to me. I do not mean to say that the next generation lacked political and social consciousness. However, I don't find my students today are willing to challenge me in the classroom. Since I became a professor in the ancient history department at the University of Granada, I have witnessed a wave of disinterest. When I lecture nobody raises a hand to question anything but only to ask me to repeat whatever I just said. They write and write, page after page, uncritically, and memorize and memorize like automatons. So different from my experience as a student when we organized the critical trials for the professors and questioned their content and the bibliographies they made available to us. Our Geography and History majors organized an assembly to discuss the purpose of the disciplines, and the meaning of history and how to create a critical inclusive understanding of human experience. ${ }^{15}$ The university has undergone a transformation, from being a space of contestation and critical thinking to just becoming a site of conformity and competition for grades. The social and political drive we had is not there in my students' reality.

Revista Monográfica 11 (1995): 9-25; Ángel Suárez, Libro blanco sobre las cárceles franquistas: 19391976 (Paris: Ruedo Iberico, 1976); Nancy Vosburg, "Prisons with/out Walls: Women's Prison Writings in Franco's Spain," Monographic Review/Revista Monográfica 11 (1995): 121-36; Lidia Falcón, En el infierno: Ser mujeren las cárceles de España (Barcelona: Ediciones de Feminismo, 1977); Eva Forest, From a Spanish Jail (New York: Penguin, 1975). Eva Forest and Lidia Falcón were involved in a bitter fight as the former implicated Falcón in the proceedings following the ETA terrorist attack in a cafeteria in the Calle del Cirreo in Madrid. Eva Forest managed to secure a number of hiding flats for ETA operatives from around 200 intellectuals like Falcón and artists in Madrid. Forest spent three years in prison and Lidia Falcón eight months. Both women wrote of their prison experience in testimonies.

15 The practice of critical trials was an extended tactic among the 1968 generation who appreciated the Situationist International language and strategies. As Cerd-Rainer Horn points out, "They began to create situations, brief moments in time and space, which pointed out to anyone willing to look and listen the absurdity of life as currently organized and the possibility of a radical shake-up, if only people were willing to jump out of their own shadows. 'So far philosophers and artists have only interpreted situations; the point now is to transform them. Since man is the product of situations he goes through, it is essential to create human situations.' And so, they did." Horn, The Spirit of '68, Kindle. Situationist International operatives were invested in the urban environment, seeking hidden meanings in the quotidian and producing poetic and artistic situations to induce a non-alienating environment they felt the cities created. There was a close collaboration between the leading figure of the Situationists, Guy Debord, and Henri Lefevbre. The shift towards a mostly political rather than artistic outlook caused some Situationist artists to distance themselves from the movement. Again, Horn explains: "This paradigm shift from cultural to political action engendered the increasing distance of several leading Situationist artists from the International's project, most notably Asger Jorn and Constant Nieuwenhuys. Their central role in the Situationist universe was taken over by Raoul Vaneigem instead, a student of the poetry of Lautreamont, introduced to Debord by their mutual acquaintance, the Marxist sociologist of everyday life and urban encounters, Henri Lefebvre." Horn, The Spirit of '68, loc. 246 of 4087, Kindle. 